\title{
Zircon record of the igneous and metamorphic history of the Fiskenæsset anorthosite complex in southern West Greenland
}

\author{
Nynke Keulen, Tomas Næraa, Thomas F. Kokfelt, John C. Schumacher and Anders Scherstén
}

The Fiskenæsset complex in southern West Greenland is part of the North Atlantic craton and is a layered intrusion consisting of gabbro, ultramafic and anorthositic rocks that was deformed during multiple episodes of folding and metamorphism (Myers 1985). We collected late-stage magmatic hornblenditic dykes and adjacent anorthosites and studied these samples integratively with several in situ techniques to determine the igneous and metamorphic history of the Fiskenæsset complex. The work presented here is part of an ongoing joint project between the Greenland Bureau of Minerals and Petroleum and the Geological Survey of Denmark and Greenland (GEUS). Here we report on new radiometric ages and mineral chemistry data from anorthosites from the North Atlantic craton in southern West Greenland (Fig. 1).

\section{Geological setting of Majaqqap Qaava}

Despite the intense Archaean deformation of the Fiskenæsset area the original stratigraphy of the Fiskenæsset complex was established from detailed field work at Majaqqap Qaava (Myers 1985). Towards the top part of the Fiskenæsset complex hornblenditic pegmatite pipes cut the generally anorthositic and leucogabbroic layering. At Majaqqap Qaava, subvertical hornblenditic dykes are interpreted as representing a late magmatic stage of activity within the Fiskenæsset complex (Myers 1985). The Fiskenæsset complex is surrounded and intruded by younger, mainly tonalitic gneisses (2.87-2.85 Ga; Næraa \& Scherstén 2008) that typically occur as felsic sheets intruded parallel to the magmatic layering. Regional amphi-

Fig. 1. Simplified geological map of the central part of the North Atlantic craton in southern West Greenland showing Majaqqap Qaava in the Fiskenæsset complex. Based on maps published by the Geological Survey of Denmark and Greenland. bolite-facies metamorphism affected the rocks at Majaqqap Qaava, but no granulite-facies metamorphism was recorded for this part of the Fiskenæsset complex (Myers 1985).

\section{Zircon dating}

For $\mathrm{U} / \mathrm{Pb}$ zircon age determination we selected sample GGU 508216, which consists of hornblenditic dyke material and the surrounding anorthosite rock. The sample was crushed, sieved, and washed on a Wilfley table. The zircons were hand-picked from the heavy mineral fraction, mounted in epoxy resin and polished. Age determination was carried out by laser ablation inductively coupled mass spectrometry using an Element2 and NewWave $213 \mathrm{~nm}$ UV-laser system at GEUS following the procedures described in Frei \& Gerdes (2009). The results are shown in Fig. 2.

The zircon spot analyses yielded a wide age span, with ${ }^{207} \mathrm{~Pb} /{ }^{206} \mathrm{~Pb}$ ages ranging from $2.70 \pm 0.03$ to $2.95 \pm 0.03 \mathrm{Ga}$ (Fig. 2A; 50 concordant grains out of 54). The oldest zircon grains in our sample are c. $2.95 \mathrm{Ga}$ (Fig. 2A), which probably represents the intrusion age of the anorthosite complex. New data by A. Polat and co-workers are consistent with this interpretation, as they obtained a $\mathrm{Sm}-\mathrm{Nd}$ isochron age of c. $2.97 \mathrm{Ga}$ and $\mathrm{a}^{207} \mathrm{~Pb} /{ }^{206} \mathrm{~Pb}$ age of $2.95 \mathrm{Ga}$ for the intrusion of

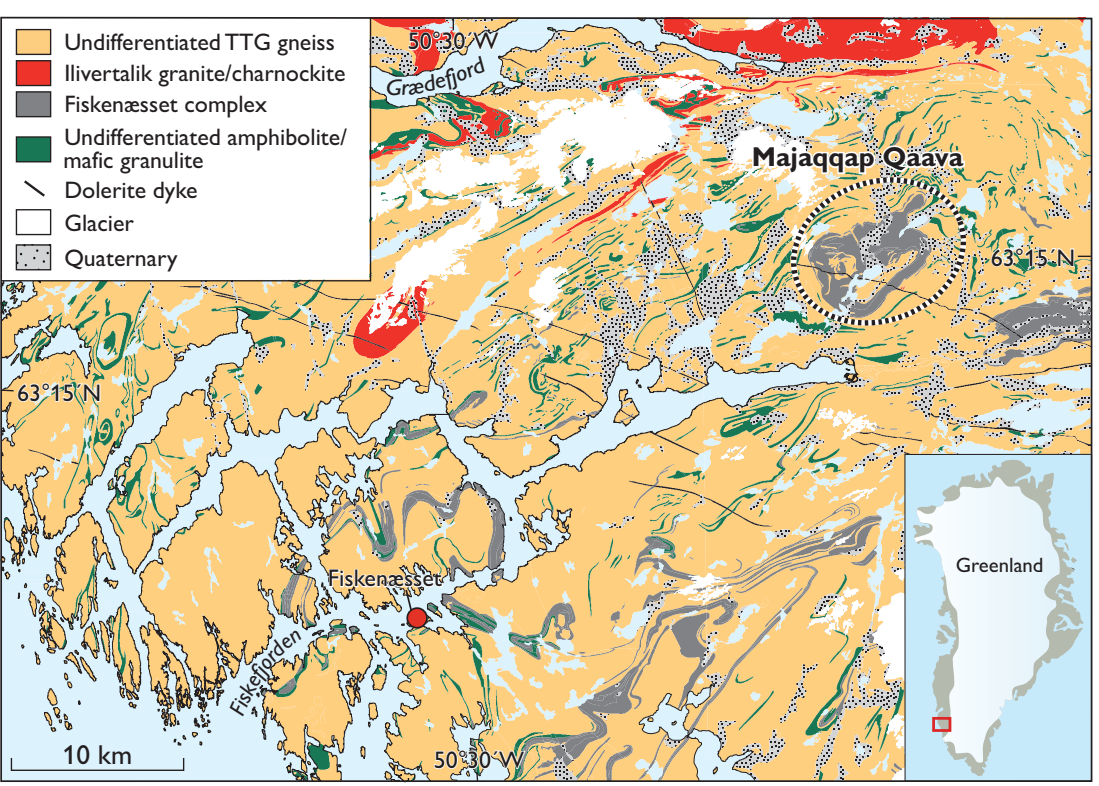



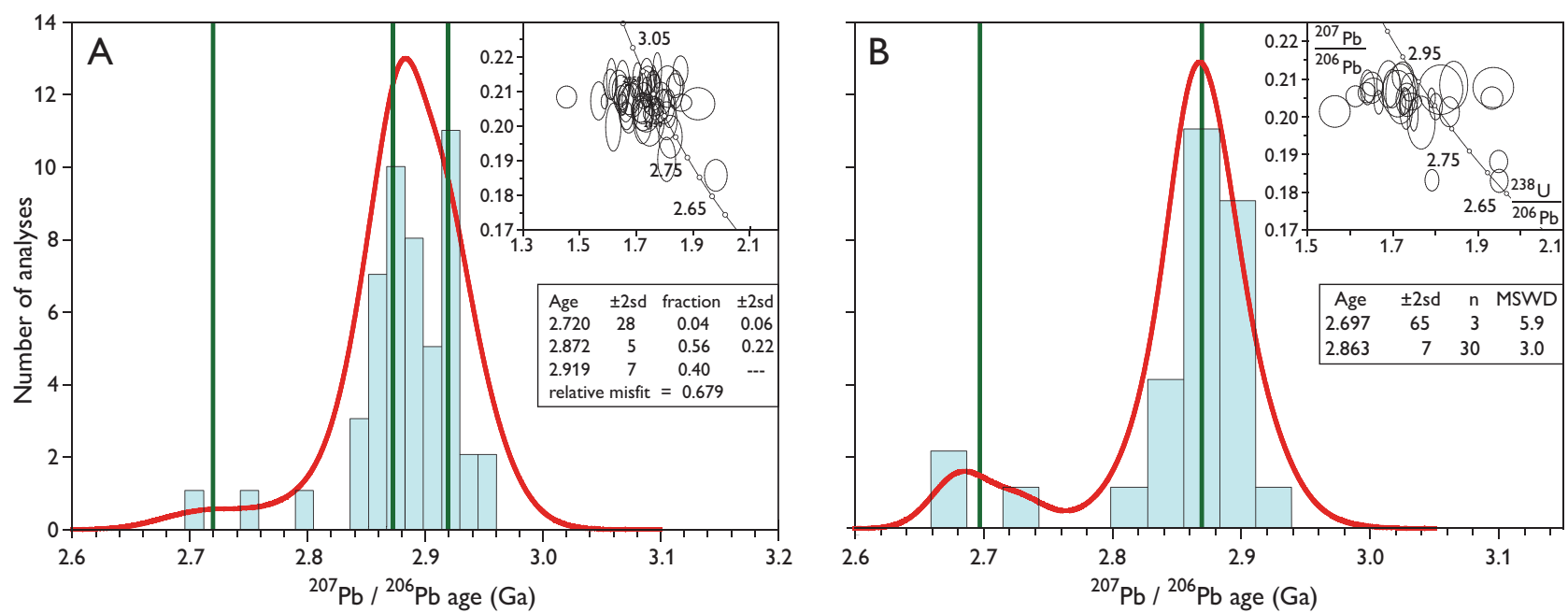

Fig. 2. Zircon $\mathrm{U} / \mathrm{Pb}-\mathrm{Pb} / \mathrm{Pb}$ age distributions from hornblenditic dyke material and anorthosite from sample GGU 508216. A: Zircon grains handpicked from crushed material with $90-110 \%$ concordant grains. Unmixing of all grains following Ludwig (2003). B: In situ dating of zircon grains with 90-110\% concordant grains. MSWD: mean square weighted deviation. n: number of analyses. The green lines show ages discussed in the text.

the Fiskenæsset complex (A. Polat, personal communication 2010). Among the dated, hand-picked grains there appear to be two populations, one at $2.92 \mathrm{Ga}$ and another at $2.87 \mathrm{Ga}$ (Fig. 2A). A third possible component at c. 2.70 Ga might represent a minor population of metamorphic grains. A known thermal event at $2.80 \mathrm{Ga}$ involving granulite-facies metamorphism that affected the western part of the Fiskenæsset complex and the intrusion of the Ilivertalik granite (T. Næraa \& A. Scherstén, unpublished data) is not recorded among the dated zircon grains from Majaqqap Qaava.

\section{In situ observations}

To better understand the three zircon-forming events (c. 2.92, c. 2.87 and c. $2.7 \mathrm{Ga}$ ), we observed the zircon grains in situ in polished slabs of the anorthosite samples using the scanning electron microscope at GEUS and the electron microprobe at the University of Copenhagen. Zircon grains occur in four different textural settings: (1) associated with ilmenite within the hornblenditic dyke (Fig. 3A), (2) within the hornblenditic dyke, (3) in melt pockets associated with the hornblenditic dyke (Fig. 3B) and (4) in cracks associated with chlorite (Fig. 3C). A further feature in the hornblenditic dyke in the anorthosite is the break-down reaction of the ilmenite in the hornblende to form rutile, titanite and chlorite (Fig. 3D). We dated zircon grains from these four different settings in situ using the same ICP-MS instrument as described above.

\section{Interpretation}

Based on the in situ observations and measurements, our current understanding of the igneous and metamorphic history of the anorthosite at Majaqqap Qaava is as follows: After intrusion of the anorthosite at $c$. 2.97-2.95 Ga, zircon formed at high-temperature conditions, e.g. from a reaction between baddeleyite and ilmenite. Some of these zircon grains can be observed next to ilmenite grains (Fig. 3A); however, no concordant ages were obtained from the in situ measurements.

A later thermal event occurred at c. $2.92 \mathrm{Ga}$, which forms the major age component in the zircon population extracted from the crushed sample (Fig. 2A). Since only one in situ zircon measurement yields $2.92 \mathrm{Ga}$, the true nature of this event is unclear. This age might be related to an igneous event that formed the precursors to the amphibolite units in the area (see e.g. Nutman et al. 2004), or the earliest onset of tonalitic gneiss formation in the region (Næraa \& Scherstén, unpublished data).

Zircon grains from the contact region between the hornblenditic dyke and the anorthosite were observed both in relation to melt pockets (Fig. 3B) and as occurring in the amphibole-anorthite assemblages. These different textural settings yield indistinguishable zircon ${ }^{207} \mathrm{~Pb} /{ }^{206} \mathrm{~Pb}$ ages of 2.878 $\pm 0.011 \mathrm{Ga}$ (mean square weighted deviation $=0.33$ ) and $2.856 \pm 0.016 \mathrm{Ga}$ (mean square weighted deviation $=1.3$ ), respectively. There is, however, a large range in ages between the individual analyses. We suggest that this wide age range originates from inheritance or metamorphic overprinting, but the mean age reflects the crystallisation or resetting related to the intrusion of the hornblenditic dykes. The melt pockets in the hornblenditic dykes are likely to represent their final solidification. If correct, and if this age is representative, it implies that the dykes represent a late magmatic event, much later than previously assumed. This interpretation is at odds with field observations, which are best ex- 

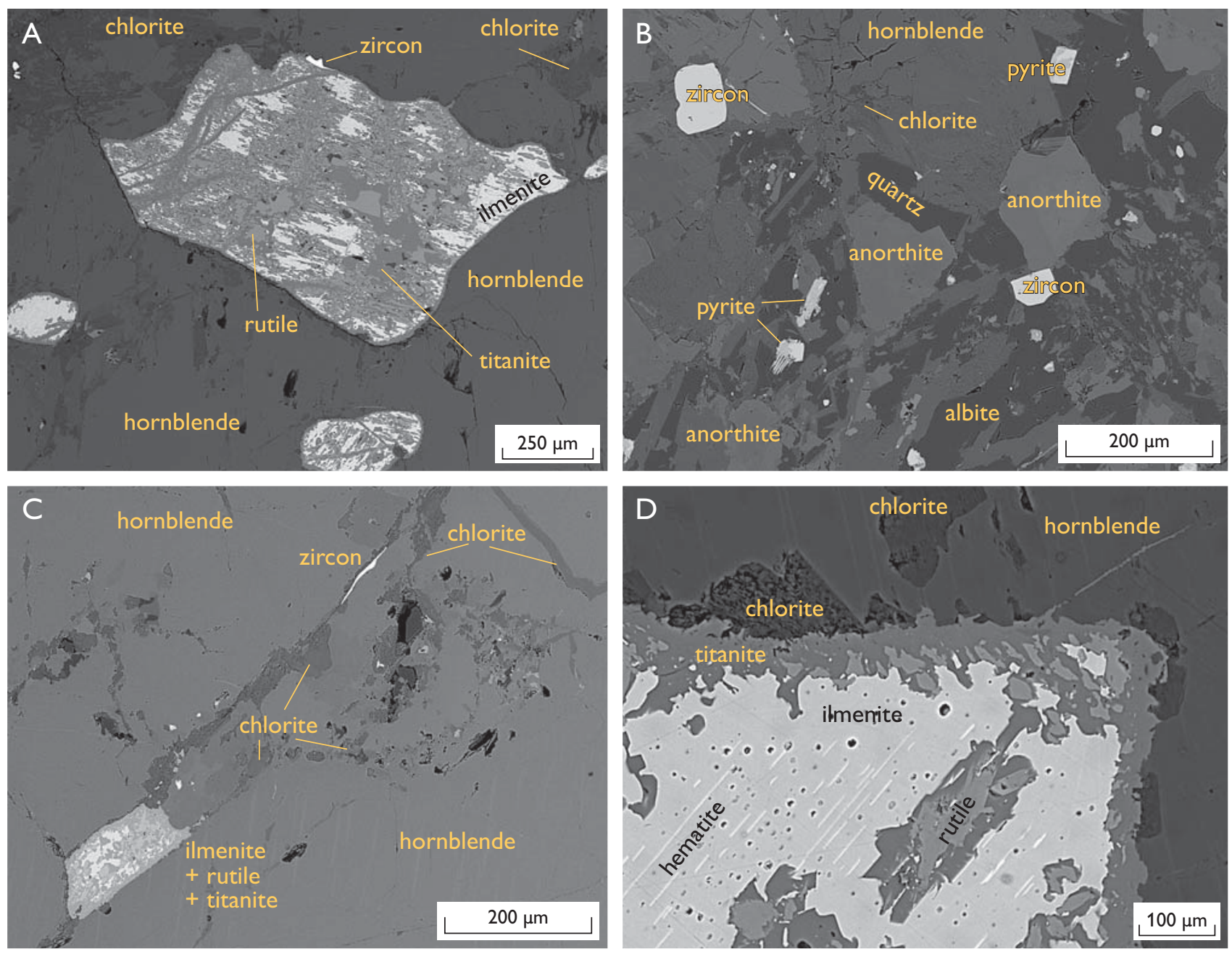

Fig. 3. Backscatter electron contrast mode scanning electron microscope images showing the textural association of zircon grains in the sample GGU 508216 and the observed break down reaction of ilmenite. A: Zircon associated with ilmenite. B: Zircon grains in melt pockets associated with the hornblenditic dyke that intruded into the anorthosite. C: Zircon in chlorite-filled cracks. D: Ilmenite in hornblende has reacted with water to form chlorite, titanite and rutile. Detail of the central grain shown in A.

plained by their intrusion into a partly solidified anorthosite crystal mush rather than a brittle solid. Alternatively, part of the hornblenditic dykes could have remelted during the intrusion of tonalitic gneisses in the area at this time (Nutman et al. 2004; Næraa \& Scherstén 2008). After further cooling hematite lamellae exsolved in the ilmenite, and these lamellae are seen as thin needles in the ilmenite grains (Fig. 3D).

The observed reaction microstructures (Fig. 3D) suggest partial hydration of the assemblage hornblende + ilmenite, which yields the reaction products chlorite + rutile + titanite. This assemblage does not contain quartz. The reaction products are concentrated at the grain boundaries between hornblende and ilmenite, which suggests that the reactions are driven by small amounts of fluid present at the grain boundaries. Since the anorthosites are dry, the extent to which retrograde metamorphic changes can be recorded is a function of the amount of water brought into the system by the hornblenditic dykes. The reactions are likely to have ceased after all the local fluid was consumed. Assuming the reactions took place in an essentially closed system, as waterrich chlorite grew, the composition of the fluid could show considerable variation.

Within the chlorite-filled cracks in the hornblende-rich parts of the sample, newly grown zircon grains up to $100 \mu \mathrm{m}$ in length are found (Fig. 3C). These zircon grains appear to fill the interstitial space between the chlorite-rimmed hornblende grains. The source of zirconium to form these zircons is most probably the ilmenite grains that broke down in the reaction discussed above. The age of the zircon grains in these chlorite-filled cracks is poorly constrained at $2.70 \mathrm{Ga}$ (Fig. 2B), but this age is in good accordance with the interpretation that the ilmenite break-down reaction occurred 


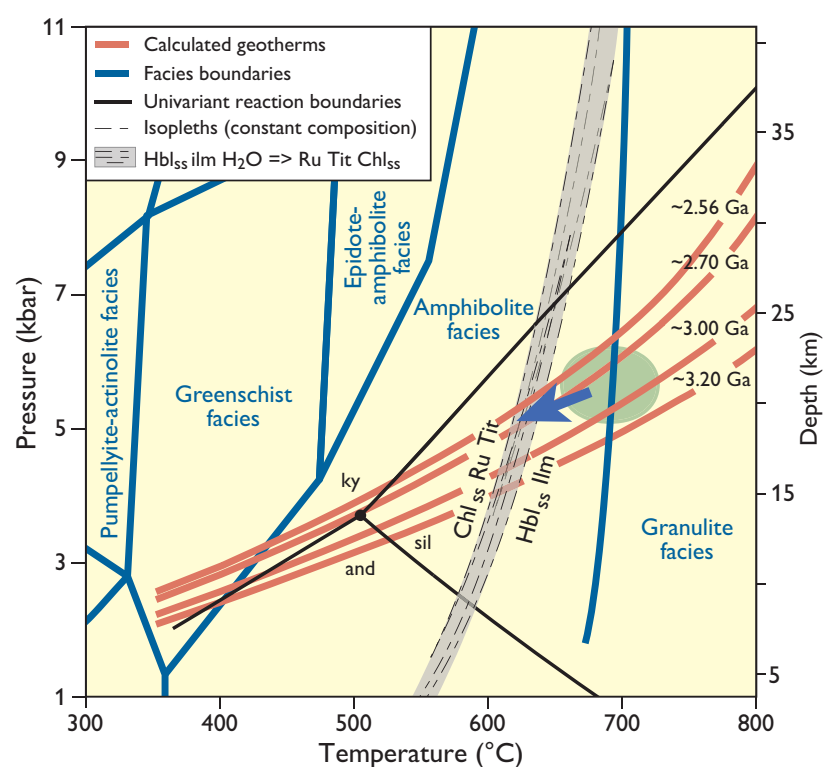

Fig. 4. Pressure-temperature $(P-T)$ diagram that shows ranges of $P-T$ estimates for modelled compositions of chlorite. The geotherms are based on measured and estimated content as a function of time of radiogenic elements in basaltic and felsic Greenland rocks (see Keulen et al. 2009 for further explanation). The pale-green area is the peak $P-T$ conditions for regional metamorphism as suggested by Keulen et al. (2009). The blue arrow is part of a possible cooling path. Ru: rutile. Tit: titanite. $\mathbf{C h l}_{\mathbf{s s}}$ : chlorite solid solution. $\mathbf{H b}_{\mathbf{s s}}$ : hornblende solid solution. Ilm: ilmenite. $\mathbf{k y}$ : kyanite. sil: sillimanite. and: andalusite.

shortly after peak metamorphism (see below). Regional metamorphism was previously dated at $2.72 \mathrm{Ga}$, based on material from the Nuuk region (e.g. Friend et al. 1996) and the same age was reported north of Ilivertalik by Næraa \& Scherstén (2008).

\section{Modelling of the metamorphic reaction}

Modelling of reactions to determine the approximate conditions of formation is complicated by extensive compositional variation of the amphibole and by potential variation in the fluid composition. Nevertheless, when using PerPlex (Connolly 2005) it is possible to locate mineral composition isopleths that approximate microprobe data for the amphibole and chlorite. Modelled compositions are: chlorite: $X_{\mathrm{Mg}}=$ 0.81-0.84; hornblende: $X_{\mathrm{Mg}}=0.70-79$; Al per formula unit $=1.490-1.626$, and measured compositions are: chlorite: $X_{\mathrm{Mg}}=0.65-0.75$; hornblende: $X_{\mathrm{Mg}}=0.76-0.80 ; \mathrm{Al}$ per formula unit $=1.50-1.75$.
The PerPlex modelling results are shown in Fig. 4. These results fit well with peak metamorphic conditions suggested by Keulen et al. (2009). Figure 4 shows the pressure-temperature region relevant to the mineralogy of the studied sample. The reaction seems to have occurred just after peak metamorphic conditions at about $600^{\circ} \mathrm{C}$ and after peak metamorphism in the area.

As a result of this pilot study on zircon grains and their surrounding minerals in samples from Majaqqap Qaava within the Fiskenæsset complex, southern West Greenland, we are able to show that the anorthosite records a metamorphic history that is more complex than previously recognised. Careful in situ observations prove helpful in unravelling the history of these rocks.

\section{Acknowledgements}

Alfons Berger is thanked for help at the microprobe, and Fiorella Fabra Aguilera and Mojagan Alaei are thanked for help with sample preparation.

\section{References}

Connolly, J.A.D. 2005: Computation of phase equilibria by linear programming: A tool for geodynamic modeling and its application to subduction zone decarbonation. Earth and Planetary Science Letters 236, 524-541.

Frei, D. \& Gerdes, A. 2009: Precise and accurate in situ U-Pb dating of zircon with high sample throughput by automated LA-SF-ICP-MS. Chemical Geology 261, 261-270.

Friend, C.R.L., Nutman, A.P., Baadsgaard, H., Kinny, P.D. \& McGregor, V.R. 1996: Timing of late Archaean terrane assembly, crustal thickening and granite emplacement in the Nuuk region, southern West Greenland. Earth and Planetary Science Letters 142, 353-365.

Keulen, N., Scherstén, A., Schumacher, J.C., Næraa, T. \& Windley, B.F. 2009: Geological observations in the southern West Greenland basement from Ameralik to Frederikshåb Isblink in 2008. Geological Survey of Denmark and Greenland Bulletin 17, 49-52.

Ludwig, K.R. 2003: Mathematical-statistical treatment of data and errors for ${ }^{230} \mathrm{Th} / \mathrm{U}$ geochronology. Uranium-Series Geochemistry, Reviews in Mineralogy and Geochemistry 52, 631-656.

Myers, J.S. 1985: Stratigraphy and structure of the Fiskenæsset complex, southern West Greenland. Bulletin Grønlands Geologiske Undersøgelse 150,72 pp.

Næraa, T. \& Scherstén, A. 2008: New zircon ages from the Tasiusarsuaq terrane, southern West Greenland. Geological Survey of Denmark and Greenland Bulletin 15, 73-76.

Nutman, A.P., Friend, C.R.L., Barker, S.L.L. \& McGregor, V.R. 2004: Inventory and assessment of Palaeoarchaean gneiss terrains and detrital zircons in southern West Greenland. Precambrian Research 135, 281-314.

\footnotetext{
Authors' addresses

N.K., T.N. \& T.F.K., Geological Survey of Denmark and Greenland, Øster Voldgade 10,DK-1350 Copenhagen K, Denmark. E-mail:ntk@geus.dk J.C.S., Department of Earth Sciences, University of Bristol, Bristol BS8 1RJ, UK.

A.S., Department of Earth \& Ecosystem Sciences, Lund University, Sölvegatan 12, S-223 62 Lund, Sweden.
} 